\title{
ex-caV/ARe. Ibridazioni digitali per la ri-presentazione delle cave campane
}

\author{
Giuseppe Antuono \\ Valeria Cera \\ Vincenzo Cirillo \\ Emanuela Lanzara
}

\section{Abstract}

I siti ex-estrattivi rappresentano una delle maggiori sfide per le politiche di rigenerazione territoriale in Europa e nel mondo, definiti spesso, nelle loro connotazioni spazio-tipologiche, con accezioni che ne lasciano generalmente intendere qualità negative non evidenziando il loro valore di paesaggi culturali. Nonostante un preliminare e non esaustivo contesto normativo di riferimento nazionale e regionale, il tema della valorizzazione di tali ambiti necessita di maggiore attenzione da parte della comunità scientifica, soprattutto nel rispetto dell'attuale scenario internazionale (Direttiva Europea 85/337). Nello specifico, per la sua numerosa concentrazione di aree estrattive, peculiare attenzione merita la realtà territoriale della regione Campania, con la messa a punto di un sistema informativo aperto da cui desumere una rappresentazione sinottica dello stato di fatto che integri l'identità storico-culturale con la dimensione figurativa e percettiva dei luoghi.

Parole chiave

paesaggio, percezione e visualizzazione, rilievo, sistema informativo, fruizione virtuale e immersiva.

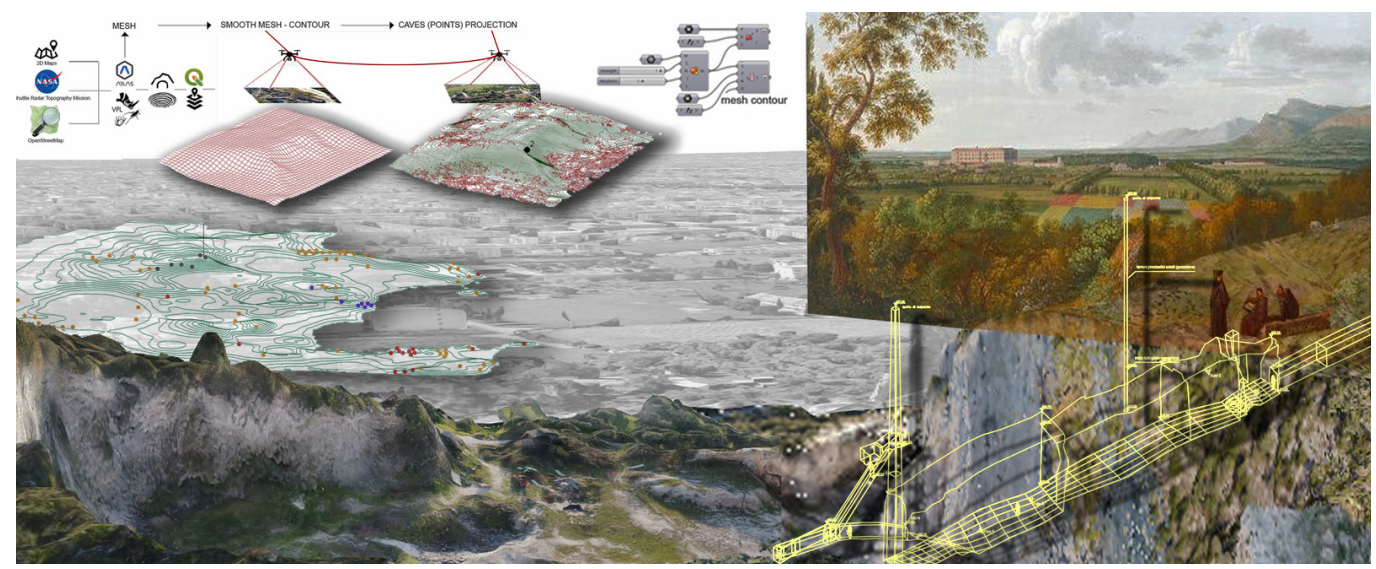




\section{Le cave. Uno spazio vuoto come modello fisico e percettivo in continuo divenire}

II contributo, sviluppato nell'ambito della rappresentazione digitale, presenta un'indagine sull'acquisizione integrata di rilievo e modellazione dei dati relativi al sistema delle cave campane. II rilievo fotogrammetrico SfM da UAV, l'uso di tecniche di modellazione VPL e l'implementazione di una piattaforma GIS, hanno favorito una più ampia indagine della realtà territoriale della regione Campania, caratterizzata da una configurazione paesaggistico-territoriale del sistema caveale descritta da due tipologie prevalenti: 'in sotterranea' e a 'cielo aperto'.

Una prima stima, condotta dall'analisi dei piani regionali sulle attività estrattive, mostra per la tipologia di cava 'in sotterranea' (ubicata in prevalenza nell'area urbana di Napoli con estensione anche all'area metropolitana) un censimento di 226 cave, pari a circa il I4,7\% delle cave esistenti nella regione Campania. Di queste, 23 risultano autorizzate, 23 chiuse, 180 abbandonate. In aggiunta a queste ultime, si registrano 27 cave abusive. La tipologia a cielo aperto, invece, presente in maggioranza nella provincia di Caserta, porta a rassegna complessivamente 422 cave, circa il 27,5\% di tutte quelle del territorio campano e di cui 46 autorizzate, 59 chiuse, 317 abbandonate. Le cave abbandonate della provincia di Caserta rappresentano il $29,8 \%$ del totale regionale [ $\mathrm{I}$ ]. Infine, alle 422 si aggiungono altre 36 cave abusive.

L'intensa attività estrattiva condotta su questo ampio territorio ha mutato nel corso del tempo l'immagine e il carattere percettivo-identitario dei suoi luoghi. Oltre però al mero dato numerico non emergono particolari studi di tipo grafico-percettivi delle cave che ne descrivano i significati e ne restituiscano l'identità e il senso di appartenenza al contesto. Per tali motivi, questo contributo cerca di affrontare un tema che sempre di più appartiene alle nostre realtà territoriali, con la proposta di restituire il grande palinsesto delle cave della realtà campana non più come elementi di disconnessione del territorio ma come luoghi della "possibilità di essere" [Bachelard 1999, p. 239]. All'interno di questo contesto la disciplina del disegno costituisce un medium indispensabile per lo studio e la documentazione delle cave e si configura come una prima operazione di conoscenza oggettiva e, al tempo stesso, di lettura critica. In tal senso, la ricerca, finalizzata all'acquisizione, analisi, sistematizzazione e comunicazione della configurazione paesaggistico-territoriale del sistema di cave (qui con primi esempi a Napoli e Caserta), si propone di implementare la mappatura territoriale dei siti estrattivi attraverso le più appropriate tecniche e metodologie integrate di rilievo per la loro acquisizione, per porre una particolare riflessione all'accezione della cava sia come elemento dall'insito significato di spazio vuoto che come spazio fisico e percettivo in continuo divenire [Santarelli 20I5, p. 5I].

\section{Un approccio integrato per la ri-presentazione multiscalare del sistema cave}

L'evoluzione dei processi di digitalizzazione ed informatizzazione favorisce la diffusione e la gestione dei big data legati alle risorse culturali, arricchisce le collezioni tradizionali e potenzia l'interazione dato/utente al fine di preservare e valorizzare l'identità di un patrimonio [Bianchini et al. 2019]. I vantaggi consistono nella possibilità di accesso diretto ed esplicitazione di informazioni difficilmente reperibili.

Quest'attività di ricerca dimostra come la rielaborazione speditiva e l'integrazione multidisciplinare di tali dati favorisca l'acquisizione, modellazione, sistematizzazione, informatizzazione e valorizzazione del vasto e complesso patrimonio paesaggistico-territoriale del sistema delle cave campane stimolando la ricerca di output alternativi per la rappresentazione di tali elementi a varie scale. Per 'ri-presentare' tali informazioni (cartografie, censimenti, etc.) questo contributo propone l'integrazione di software 3D Map generators, approccio VPL (Visual Programming Language), GIS (Geographic Information System), tecniche di rilevamento digitale e rielaborazione grafica finalizzata alla gestione e valorizzazione dell'elemento cava attraverso la realizzazione di prodotti digitali inediti e coordinati. L'integrazione tra modelli a vasta scala e prodotti dettagliati reality based favorisce lo studio dello spazio/ambiente 
Fig. I.Acquisizione ed esplicitazione di risorse digitali per la modellazione speditiva multiscalare di aree territorial. L'immagine mostra la definizione VPL per la combinazione e gestione di dati eterogenei relativ al territorio casertano integrabili con i dati derivanti dall'attività di rilievo eseguita sull'area.

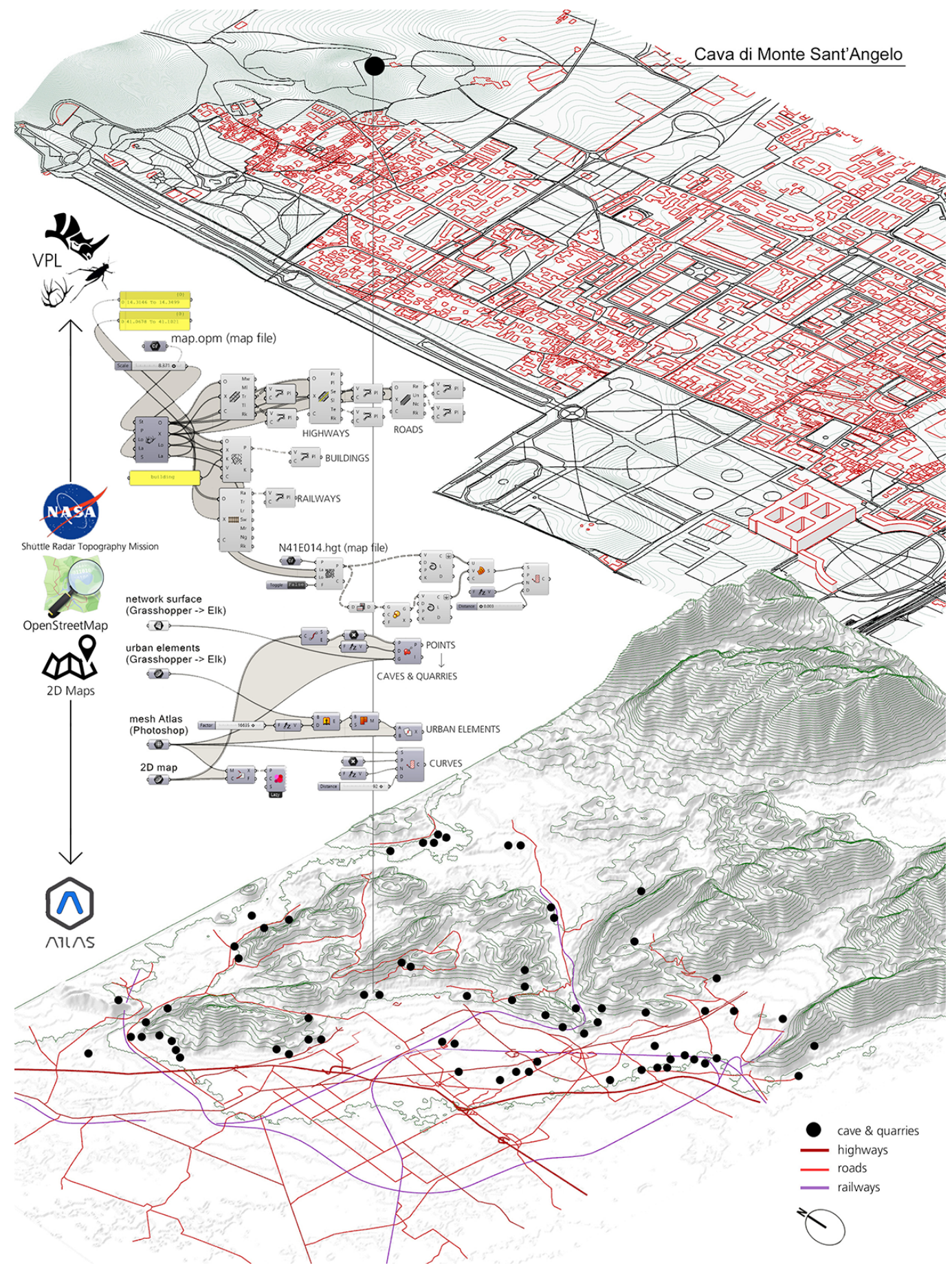


Fig. 2. Costruzione (modeling) e manipolazione smoothing e contour) de modelli di suolo (NURBS e mesh). L'immagine mostra la localizzazion delle cave più importanti distribuite nell'a distribuite nell area fle-

rea [Cardone 2008] e di studio dei Camaldoli.
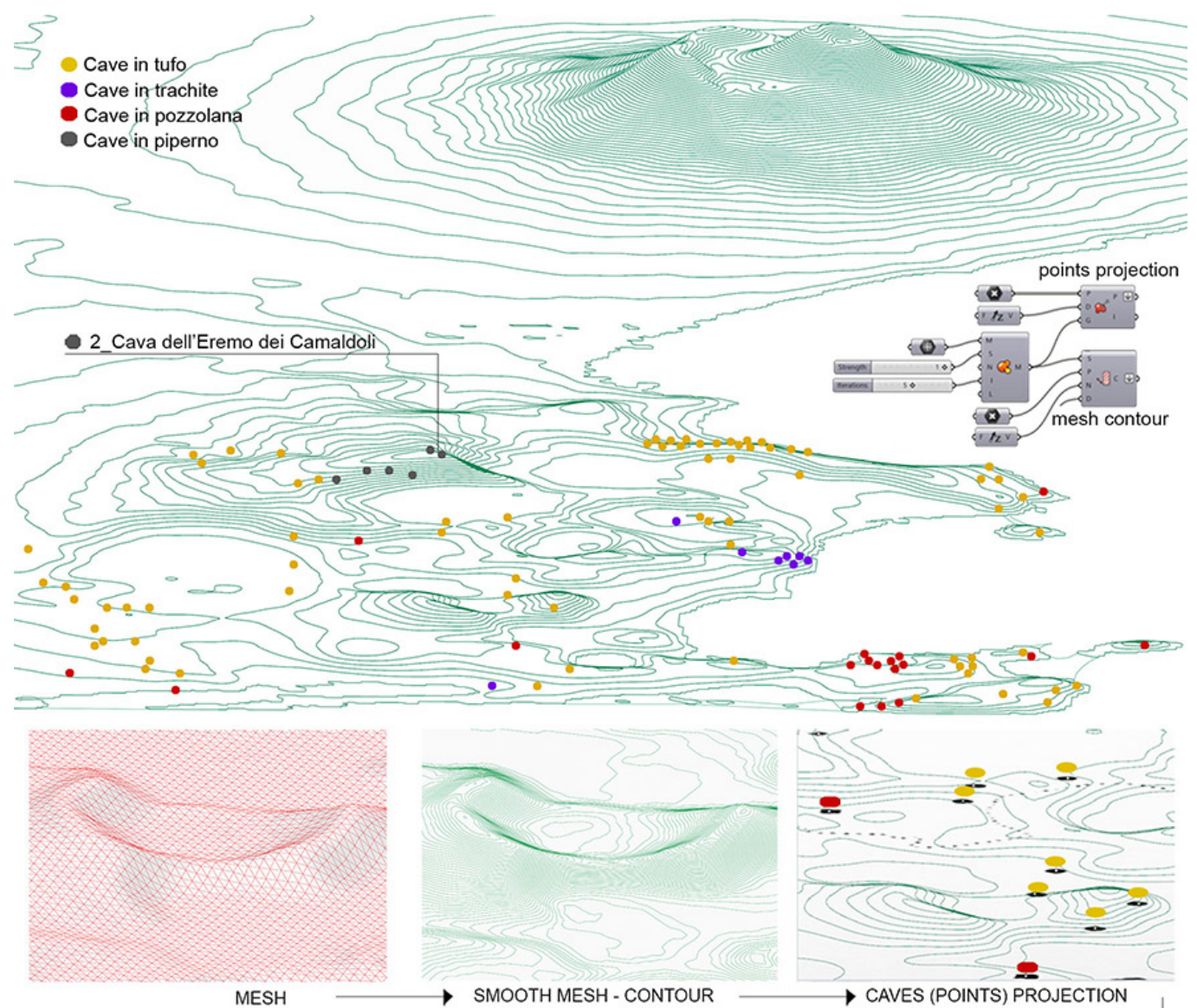

$\Delta 0$

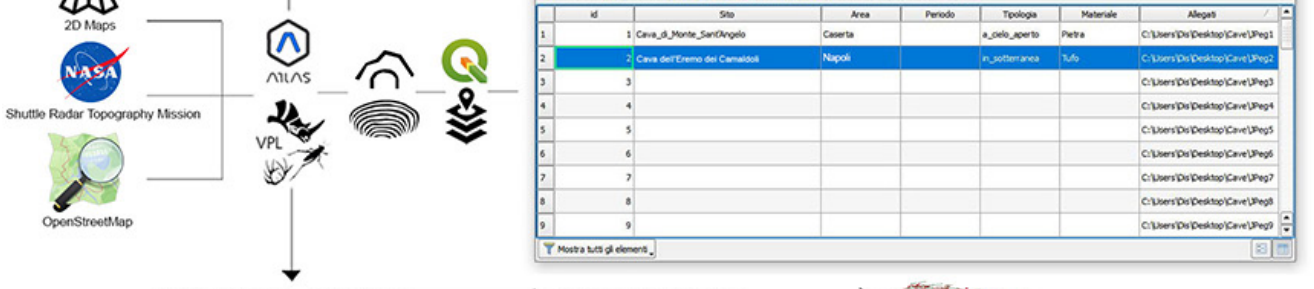

POINTS GRID - SURFACE

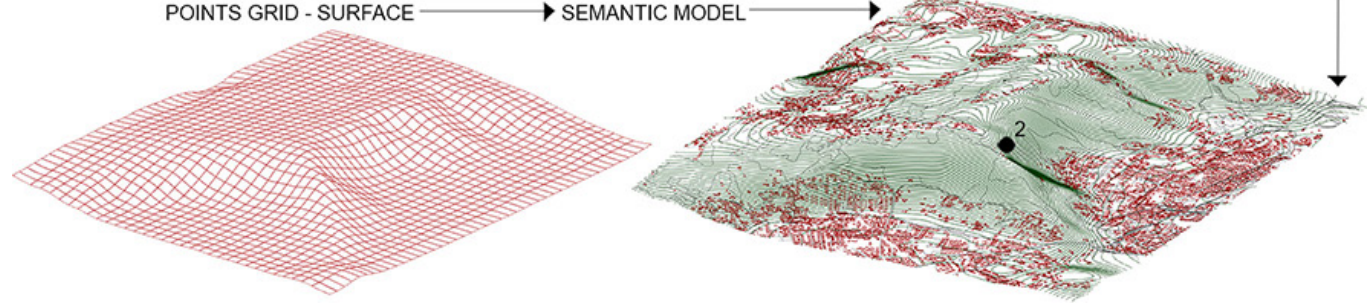


cava in chiave architettonico-compositiva. L'obiettivo è quello di sfruttare l'integrazione di approcci più o meno consolidati per strutturare nuovi sistemi informativi finalizzati ad agevolare la gestione digitale di sistemi morfologico-compositivi complessi.

Il processo consolidato di acquisizione, scomposizione, modellazione ed informatizzazione (Scan to CAD, Scan to BIM e GIS) di un sistema edificato, quindi 'aggiunto' al territorio, è finalizzato alla specializzazione di oggetti riconoscibili e gestibili [Amoruso et al. 20 I9]. II discorso si complica quando l'oggetto di tale attività deriva da una 'sottrazione' dell'elemento dal complesso involucro paesaggistico-ambientale che lo ingloba. Gli attuali strumenti digitali semplificano l'acquisizione, ma soprattutto la manipolazione e restituzione, dei big data territoriali ed urbani sotto forma di un sistema discreto (reti di punti e curve che strutturano i vari elementi e dunque consentono la restituzione dell'orografia, dei sistemi viario, edificato, etc.) che esplicita e sistematizza le informazioni territoriali contenute in map tiles geolocalizzate e disponibili su piattaforme digitali quali OpenStreetMap e Shuttle Radar Topography Mission (SRTM) (fig. I). Tale approccio, pertanto, consente la trasformazione e la messa a sistema di dati eterogenei in un modello sintetico graficizzabile ed accessibile ad un ampio numero di utenti [Calvano et al. 2016].

I digital tools generativo-computazionali (Elk, Mosquito, add-on di Grasshopper - Rhino-McNeel) sono stati utilizzati per estrarre ed integrare un DTM mesh o NURBS (in base al server consultato in relazione all'estensione dell'area da restituire) a partire dai dati digitali acquisiti in rete e integrando i dati bidimensionali esistenti (mappe grafiche riportanti la distribuzione territoriale provinciale delle cave catalogate). Le operazioni di contour e smoothing del modello digitale caratterizzano gli output grafici (fig. 2). L'individuazione dei principali sistemi viari e degli edifici significativi semplifica la localizzazione (proiezione) delle cave caso-studio sui DTM delle aree territoriali napoletana e casertana. Future sperimentazioni sull'integrazione tra l'estrazione ed integrazione dei DEM e le cave sono finalizzate ad interpretare i rapporti morfologico-compositivi up \& down tra il patrimonio costruito e le cave naturali e artificiali presenti.

\section{Le cave in sotterranea. L'eremo dei Camaldoli}

La città di Napoli si estende al centro di una regione vulcanica compresa tra l'edificio craterico del Vesuvio ad oriente e il distretto vulcanico dei Campi Flegrei ad occidente. La quasi totalità dell'agglomerato urbano sorge su terreni nati dall'attività vulcanica dei Campi Flegrei mentre il territorio comunale da un lato abbraccia una notevole parte della regione flegrea e dall'altro incontra prodotti lapidei del Vesuvio [2].

Allinterno di questa complessa compagine geologica si annoverano innumerevoli cavità sotterranee nate sia da fenomeni naturali che antropici [Cardone 2008]. Nel primo caso le cavità nascono, ad esempio, dall'incessante azione dell'acqua che nel defluire dall'entroterra al mare nel corso dei secoli ha scavato profondi solchi nei banchi tufacei (anche in superficie); nel secondo caso, invece, la ragione più comune risiede nell'estrazione del materiale da costruzione che avveniva spesso in situ. Di conseguenza, è semplice trovare all'interno del tessuto urbano una grande presenza di cavità sotterranee, di cui molte di natura privata,
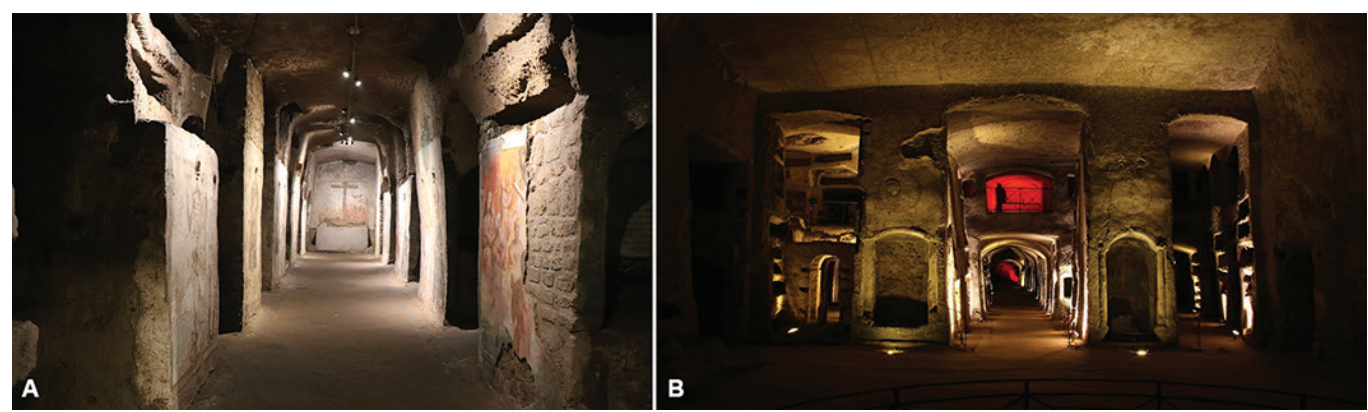


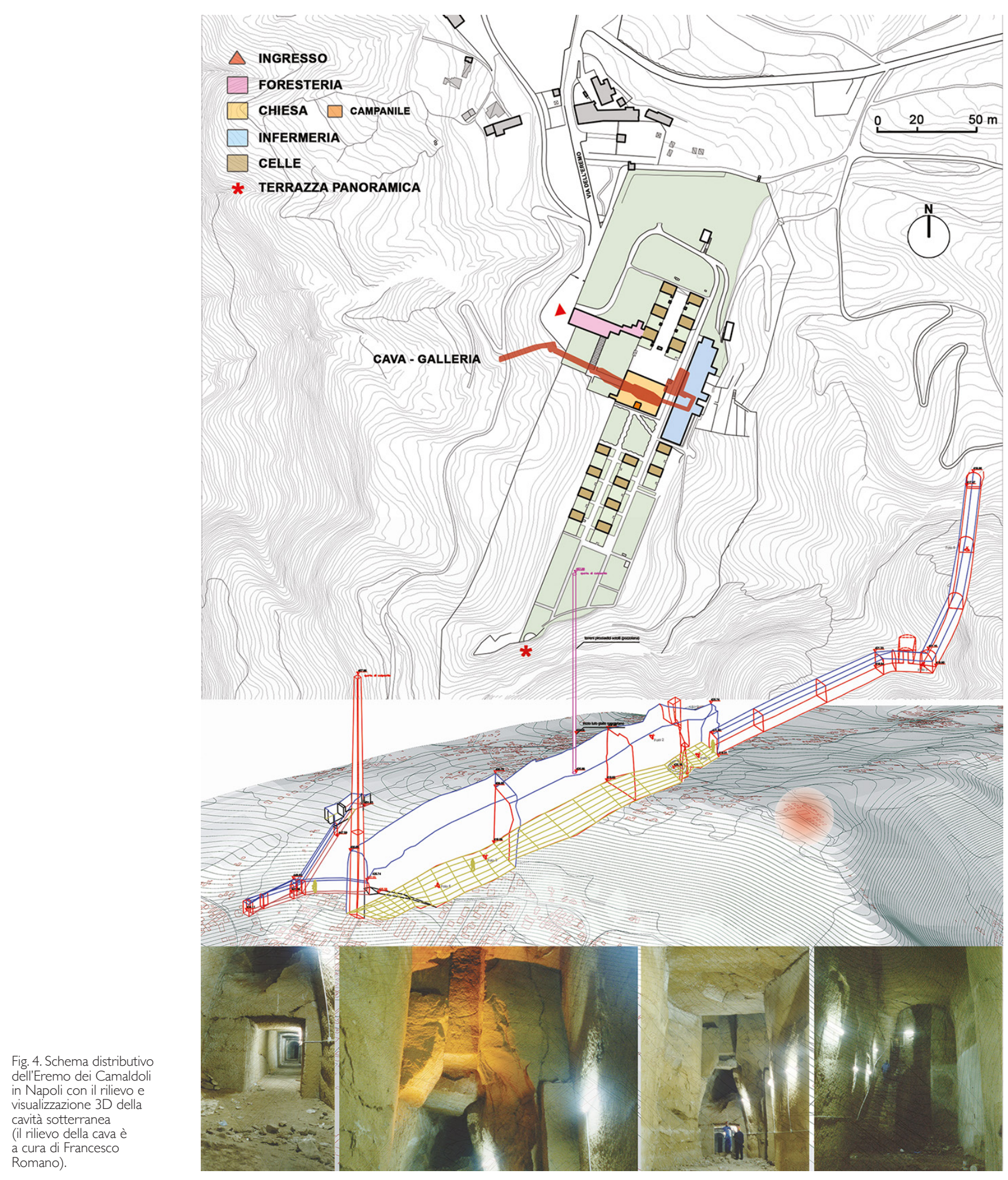


Fig. 5. Planimetria con indicazione delle aree costruite e caveali del territorio

Fig. 6. I sistema paesaggistico dei rilievi collinar di Maddaloni tra passato e presente (in rosso, le cave oggi presenti, visibil da questa prospettiva. In puntinato arancio, la

porzione di montagna oggi assente).

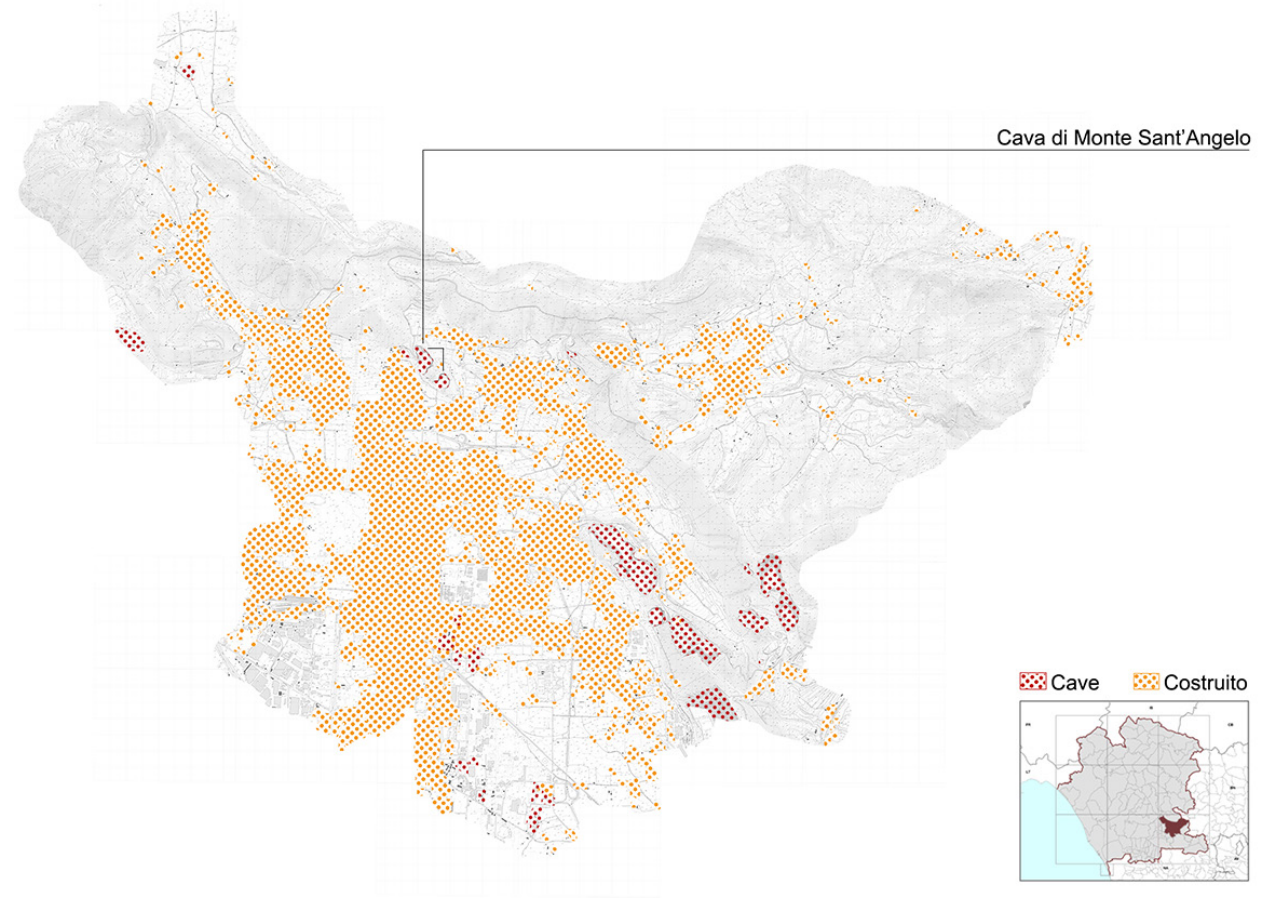

con accessi - siano essi pozzi o scale - che talvolta appaiono intasati da materiale di rifiuto oppure completamente ostruiti. Inoltre, la natura privata di queste ultime produce notevoli difficoltà di catalogazione che derivano dalla diffidenza di molti proprietari e dall'estremo frazionamento delle proprietà.

Allinterno di questo vasto panorama di cavità sotterranee, adoperate utilitaristicamente per svariati scopi, spesso sfruttandone le specifiche peculiarità, si annoverano cimiteri, catacombe, gallerie, pozzi, ripari antiaerei. L'attuale configurazione spaziale di queste cave deriva sia dal metodo di coltivazione della cava in sotterranea che dalle tecniche di scavo adottate e dalle caratteristiche geo-meccaniche del materiale estratto. Le più ricorrenti sono quelle a 'galleria con cunicoli laterali' e 'camere a pilastri' [Santarelli 20 I5, p. 20]. II primo esempio è riconducibile alle catacombe di San Gaudioso, situate al di sotto dell'attuale basilica di Santa Maria della Sanità (fig. 3a); il secondo, alle catacombe di San Gennaro che si trovano al di sotto della basilica dell'Incoronata Madre del Buon Consiglio (fig. 3b).

Questo contributo offre in prima battuta lo studio della cavità sotterranea posta al di sotto dell'eremo dei Camaldoli, un monumentale complesso religioso situato sull'omonima collina che, con i suoi quasi 500 metri sul livello del mare, rappresenta il rilievo più alto della città
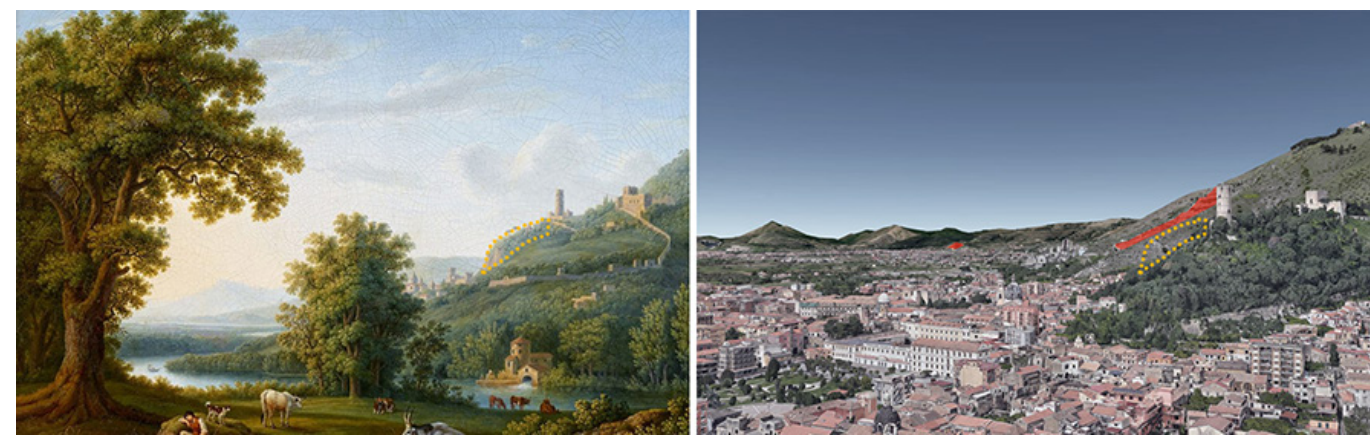
[Bossi, Ceratti 1963]. La fase di rilievo della galleria vuole rappresentare un primo tramite conoscitivo delle cave ex-estrattive a Napoli nel sottosuolo, intese come progetto del vuoto, e cerca di invocare un'apertura all'immaginario collettivo dei luoghi caveali come nuovi elementi di connessione della e nella città.

Da una prima analisi la cavità in questione risulta collocata in asse alla navata centrale della chiesa. La configurazione spaziale della cavità è riconducibile a una galleria accessibile attraverso delle scale poste nello spazio aperto di pertinenza dell'Infermeria. La galleria si compone di due spazi oblunghi dalla sezione altimetrica differente: il primo di altezza di circa 10 metri; il secondo, più piccolo, di altezza di circa 3 metri. Quest'ultimo corridoio sfocia su una stradina secondaria che costeggia l'eremo ad ovest (fig. 4).
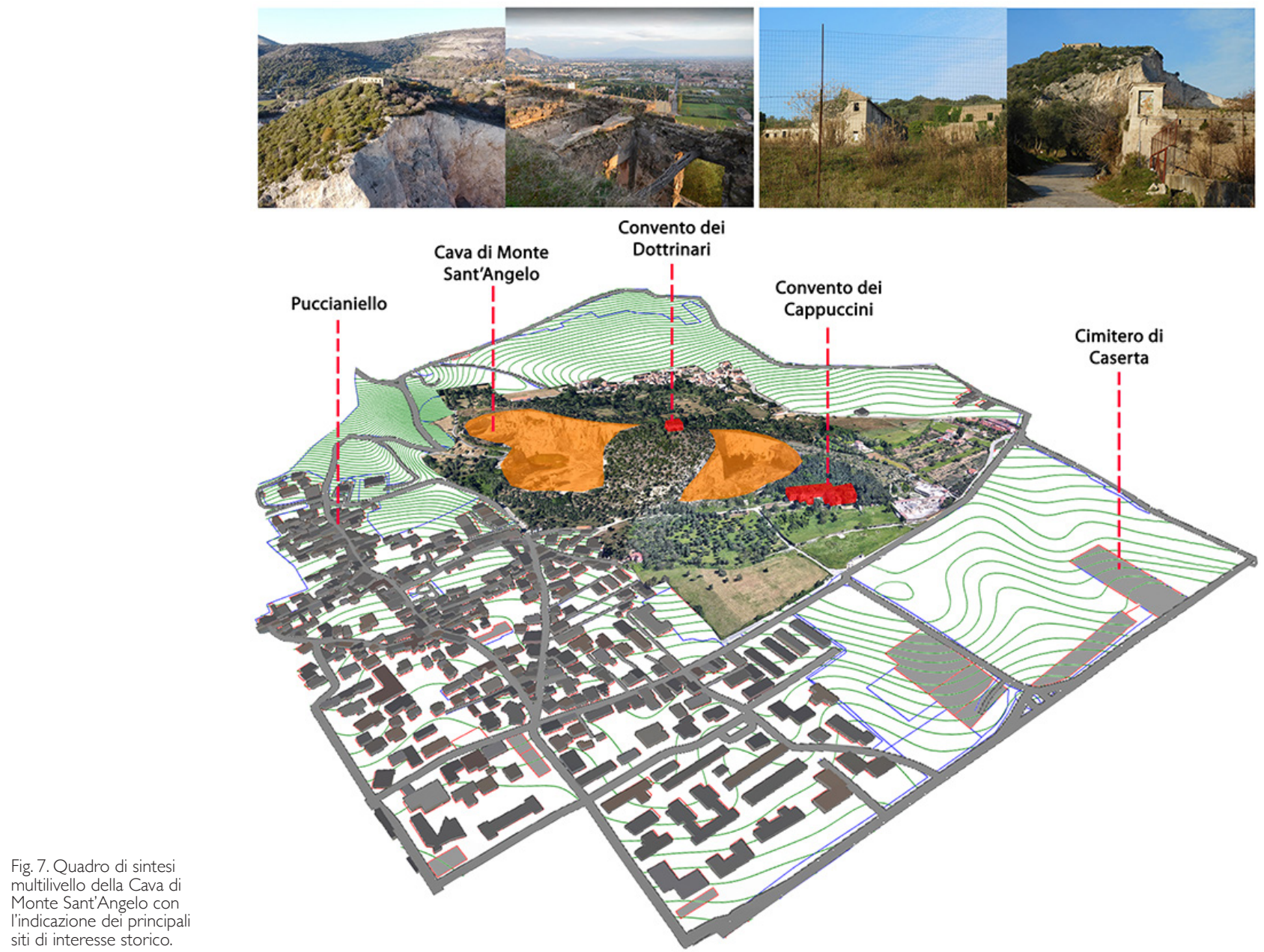

Le cave a cielo aperto. II versante dei monti Tifatini

Le coltivazioni cosiddette 'a cielo aperto' rappresentano la principale attività di approvvigionamento di materie prime per il territorio campano. II fenomeno è particolarmente evidente nella provincia di Caserta dove l'attività estrattiva degli ultimi decenni, di matrice principalmente calcarea, ha prodotto un gran numero di siti dismessi e abbandonati disseminati puntualmente lungo il versante collinare dei monti Tifatini [Buondonno 200 I] (fig. 5), sul confine nord della pianura campana, a ridosso dei principali assi infrastrutturali. Da Capua a Maddaloni (fig. 6) il contesto urbano è caratterizzato da aree terrazzate e vuoti che hanno compromesso la qualità percettiva del quadro paesistico; in particolare, l'area collinare della 
città di Caserta è caratterizzata da notevoli squarci che disconnettono la cornice paesaggistica che un tempo componeva il fondale scenico del parco della Reggia, luogo privilegiato dai viaggiatori da cui ritrarre la piana casertana (ad esempio nei dipinti di Jacob Philipp Hackert della prima metà del XVIII secolo). La zona detta di monte Sant'Angelo, per dimensioni ed esposizione delle sue pareti (alte fino a 75 metri), è rappresentativa di un sistema di forte discontinuità, fisica e percettiva; il banco calcareo, che sovrasta a nord-est l'abbandonato convento dei Cappuccini di Puccianiello (della seconda metà del XVI secolo), è il risultato di un recente processo industriale sospeso a poca distanza dalle rovine di un altro convento, quello dei padri Dottrinari, posto alla sommità della collina (a nord-ovest), della prima metà del XVII secolo, ed ormai ridotto a rudere (fig. 7). Nell'invaso artificiale è oggi possibile riconoscere un terzo paesaggio [Clément 2005], quello del limite, non solo geografico - di transizione tra città e non-città - ma anche temporale; uno spazio di attesa o di risulta che può essere ri-svelato attraverso le immagini e le iconografie dei viaggiatori che, integrate nel modello GIS, evidenziano le semplificazioni, schematizzazioni e mutazioni percettive avvenute nel tempo. II valore storico ed identitario dei luoghi ha motivato un'analisi fondata sull'integrazione di un rilievo fotogrammetrico aereo, con la georeferenziazione spaziale dei delle digital map tiles e delle fonti iconografiche e cartografiche tradizionali, per descrivere la complessità morfologica del sito e proporre interpretazioni anche storiche delle vicende di sfruttamento dell'area e della sua incidenza nella formazione del paesaggio costruito. La campagna di rilievo è stata condotta con una camera full HD, con obiettivo f/2.8, montata su drone DJI Spark; i voli sono stati eseguiti in modalità automatica seguendo il piano di volo a waypoint sia con riprese nadirali che ad asse inclinato, in ragione della conformazione geometrica del sito. Gli algoritmi SfM e multi-stereo matching [Velho et al. 2009;Török et al. 2020] hanno permesso di ricostruire la nuvola di punti ad alta risoluzione da cui ricavare un DTM, un modello altimetrico a griglia regolare e un piano quotato .tiff implementato in ambiente GIS. II confronto e l'integrazione con la morfologia territoriale ricavata dalle mappe satellitari (fig. 8), evidenzia l'importanza di un dato di rilievo accurato in ragione del grado di complessità delle strutture ivi presenti, per il controllo dell'evoluzione delle condizioni di dissesto, per la redazione dei progetti di coltivazione, nonché per costruire tematismi critici
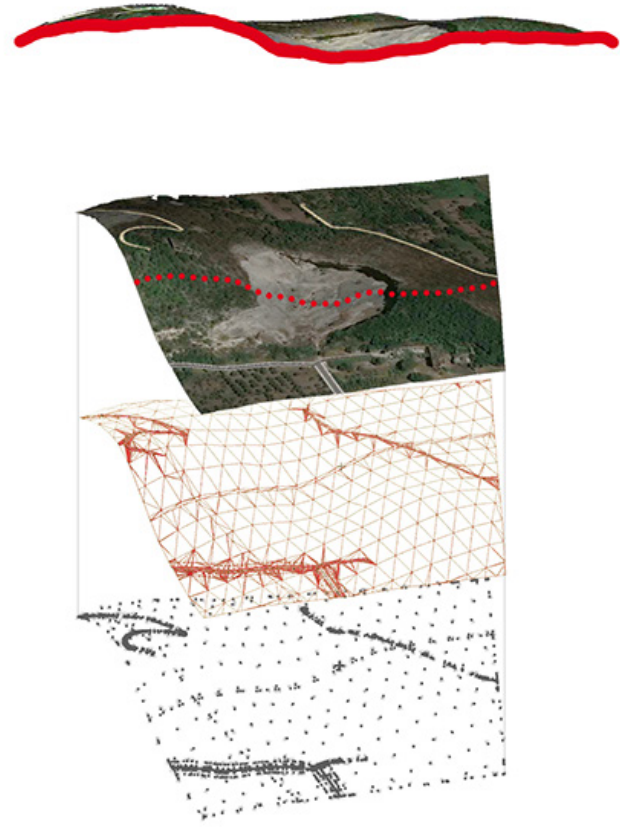
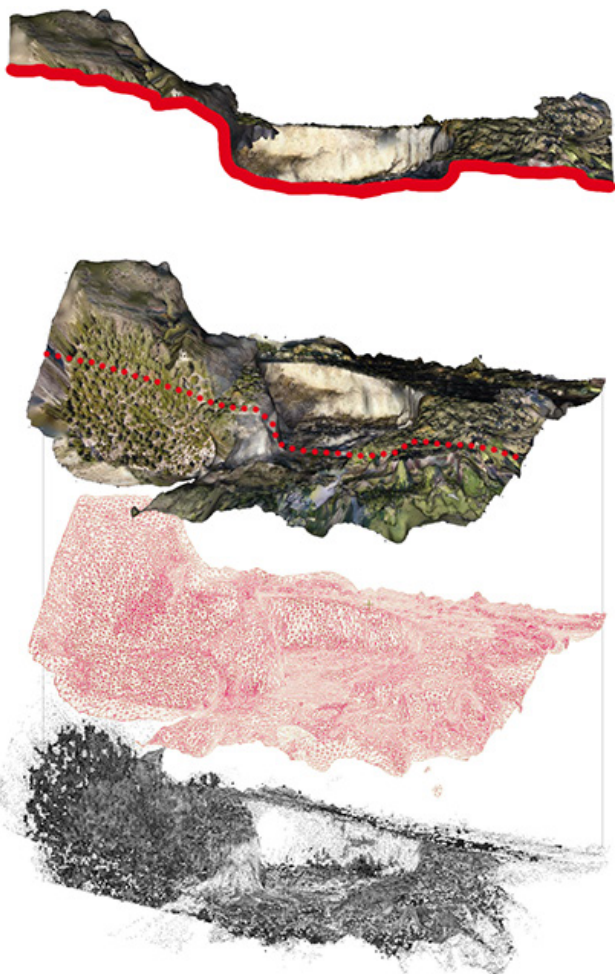
di simulazione pre o post progettuali di supporto alle attività di ripristino ambientale finalizzate ad una dimensione rinnovata dei siti caveali anche attraverso i moderni sistemi integrati di visualizzazione. Così, la visione che si manifestava al viaggiatore del Settecento riappare in un percorso virtuale suggestivo, georeferito, che descrive, oltre la componente cartografica e geometrico-configurativa, le originarie relazioni fisiche e percettive esistenti tra il sito e il contesto [Liuzzo, Giuliano 20I6] (fig. 9).

\section{Conclusioni e sviluppi futuri}

I differenti approcci adottati per l'acquisizione dei dati hanno consentito di affrontare in maniera speditiva la modellazione e gestione digitale del sistema territoriale oggetto di studio, dalla scala vasta al dettaglio. Attraverso la costruzione digitale di un database multilivello, questo studio auspica la messa a punto di una piattaforma digitale per valorizzare e divulgare i tratti di una realtà urbana e paesaggistica complessa, ibrida, caratterizzata dalla presenza di spazi frammentari, talvolta degradati, nonché considerare la possibilità di recupero del genius loci attraverso l'ausilio del disegno inteso come strumento di analisi fra pensiero e progetto [3].
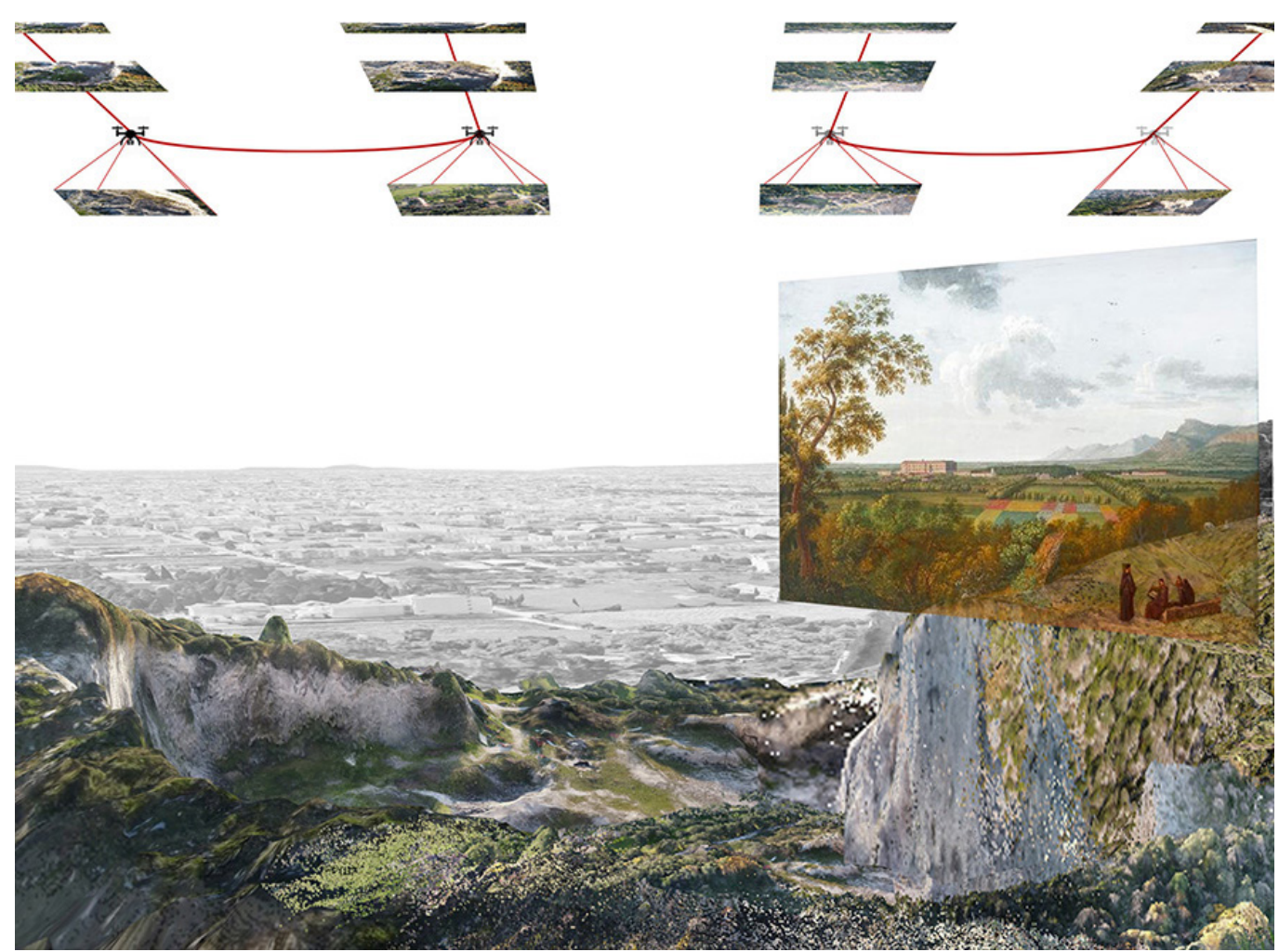

Note

[I] Linee Guida del Piano Regionale Attività Estrattive - Documento integrativo e di aggiornamento alla Relazione Conclusiva di cui alla Delibera di Giunta Regionale N 7253 del 27 dicembre 200I - giugno 2006.

[2] II sottosuolo di Napoli. Relazione della commissione di Studio. A cura del Comune di Napoli, 1967.

[3] II presente contributo è redatto in tutte le sue parti e appartiene in comune a tutti i coautori. 


\section{Riferimenti bibliografici}

Amoruso Giuseppe, Mironenko Polina (2019). Heritage BIM descriptive models for the representation of resilient city. The case of Amatrice's reconstruction. In Belardi Paolo (a cura di). Riflessioni/Reflections. L'arte del disegnolil disegno dell'arte. The art of drawing/the drawing of art. Atte del $41^{\circ}$ Convegno Internazionale dei Docenti delle Discipline della Rappresentazione. Perugia 19-2I settembre 20 19. Roma: Gangemi Editore, pp. I05 I- 1056.

Bachelard Gaston (1999). La poetica dello spazio. Bari: Dedalo.

Bianchini Carlo, Casale Andrea, Empler Tommaso et al. (2019). Ecosistemi digitali - Digital Ecosystem. In Paesaggio urbano, 1.2019, pp. 42-51.

Bossi Paolo, Ceratti Alessandro (1993). Eremi camaldolesi in Italia. Luoghi architettura spiritualità. Milano:Vita e Pensiero.

Buondonno Andrea (200I). Le aree di cava della città di Caserta: dal dissesto geopedologico alla riqualificazione ambientale. In Rigillo Marina et al. (a cura di). La Città continua. Il sistema urbano da Capua a Maddaloni. Caserta: L'Aperia editore, pp. 77-84.

Calvano Michele, Guadagnoli Francesca (2016). Ricostruzione 3D della città di Amatrice. Una operazione di 'instant modeling'. In DisegnareCon. n. 17, 2019 , vol. 9, pp. 7.1-7.9.

Cardone Vito (2008). Modelli grafici dell'architettura e del territorio. Salerno: Cues.

Clément Gille (2005). Manifesto del Terzo Paesaggio. Macerata: Quodlibet

Conti Simonetta, Valerio Vladimiro (2012). La Terra di Lavoro nella Storia. Dalla Cartografia al Vedutismo. Roma: Associazione Roberto Almagià. pp. 102-103.

Liuzzo Mariangela, Giuliano Sebastiano (2016). Dal rilievo alla divulgazione: metodologie integrate per la fruizione virtuale de territorio. In Capano Francesca, Pascariello Maria Ines, Visone Massimo (a cura di). Delli Aspetti de Paesi. Vecchi e nuovi Media per I'Immagine del Paesaggio. Napoli: FedOA - Federico II University Press, pp. 327- 336

Santarelli Isabella (2015). Riscritture per il sottoruolo ex-estrattivo. Strategie di recupero tra memoria, tutela ambientale e nuovi usi per la città contemporanea. Tesi di Dottorato di Ricerca XXVIII ciclo. Sapienza Università di Roma. DiAP, p. 20.

Török Ákos, Bögöly Gyula, Somogyi Árpád, Lovas Tamás (2020). Application of UAV in Topographic Modelling and Structural Geological Mapping of Quarries and Their Surroundings - Delineation of Fault-Bordered Raw Material Reserves. In Sensors 2020, 20, n. 489

Trasi Nicoletta (200 I). Paesaggi rifiutati Paesaggi riciclati. Prospettive e approcci contemporanei. Roma: Editrice Librerie Dedalo. Velho Luiz, Frery Alejandro C., Gomes Jonas (2009). Image Processing for Computer Graphics and Vision. Cham: Springer.

\section{Autori}

Giuseppe Antuono, Università degli Studi di Napoli “Federico II”, giuseppe.antuono@unina.it

Valeria Cera, Università degli Studi di Napoli "Federico II", valeria.cera@unina.it

Vincenzo Cirillo, Università degli Studi della Campania "Luigi Vanvitelli", vincenzo.cirillo@unicampania.it

Emanuela Lanzara, Università degli Studi di Napoli "Federico II", emanuela.lanzara@unina.it

Per citare questo capitolo:Antuono Giuseppe, CeraValeria, CirilloVincenzo, Lanzara Emanuela (2020). ex-caV/ARe. Ibridazioni digitali per la ri-presentazione delle cave campane/ex-caV/ARe. Digital hybrids to re-present campanian caves\&quarries. In Arena A., Arena M., Brandolino R.G. Colistra D., Ginex G., Mediati D., Nucifora S., Raffa P. (a cura di). Connettere. Un disegno per annodare e tessere. Atti del $42^{\circ}$ Convegno Internazionale dei Docenti delle Discipline della Rappresentazione/Connecting. Drawing for weaving relationships. Proceedings of the 42th International Conference of Representation Disciplines Teachers. Milano: FrancoAngeli, pp. I556- 1577. 


\title{
ex-caV/ARe. Digital Hybrids to Re-Present Campanian Caves\&Quarries
}

\author{
Giuseppe Antuono \\ Valeria Cera \\ Vincenzo Cirillo \\ Emanuela Lanzara
}

\section{Abstract}

Mining sites represent one of the major challenges for territorial regeneration policies in Europe and worldwide. Their space-typological connotation is often described negatively without highlighting their value as cultural landscapes. The enhancement of these areas requires greater attention from scientific community, especially according to the preliminary and non-exhaustive reference context of national and regional reference about this topic (European Directive 85/337).

Campania region especially deserves attention for its concentration of numerous extraction areas. This condition requires the development of an open information system to achieve a synoptic representation of this landscape and territorial condition.

The main goal of this research activity is to integrate historical-cultural identity and figurative-perceptive dimension of these places.

Keywords

landscape, perception and visualization, survey, informative system, virtual and immersive fruition.

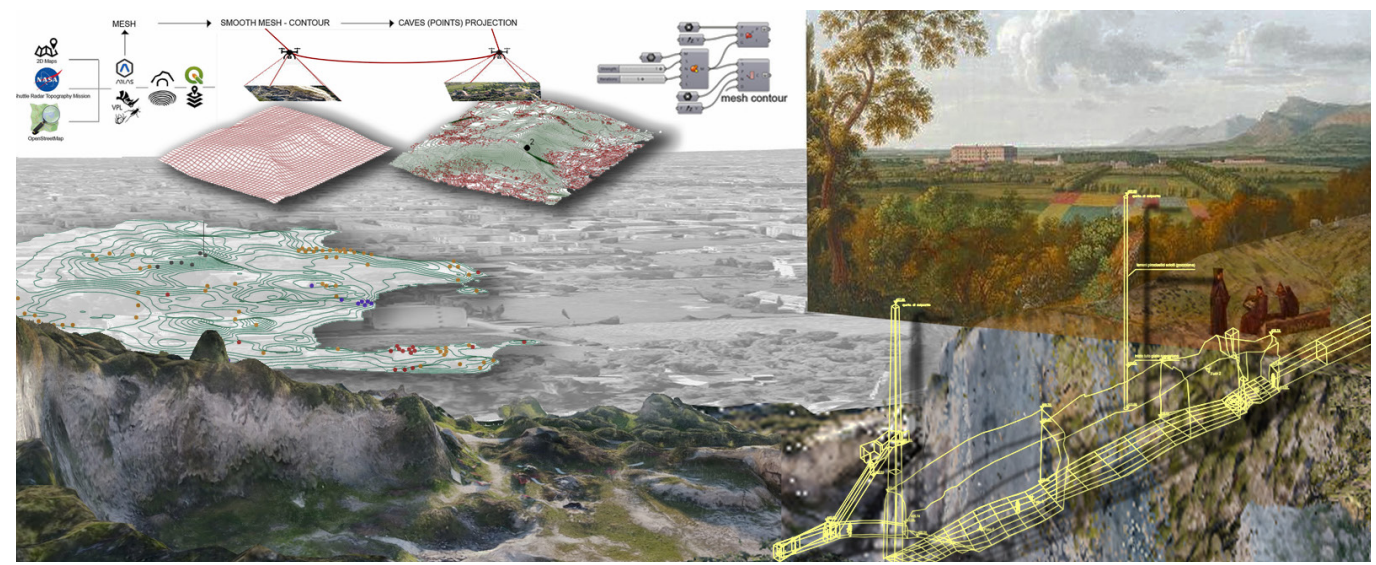




\section{The quarries. An empty space as a physical and perceptual model in constant evolution}

This contribution, developed in the context of digital representation, presents a study on the integrated acquisition survey data and modeling relating to the Campania's quarries system. The photogrammetric survey SfM from UAV, the use of VPL modeling techniques and a GIS platform implementation, have allowed a wider investigation of the Campania region's territorial reality, characterized by a landscape-territorial configuration of the quarries system described by two prevalent types: underground and open-cast.

A first estimate, conducted by analyzing the regional plans on mining activities, shows for the underground typology (mainly located in the urban area of Naples with extension also to the metropolitan area) a census of 226 quarries, about $14.7 \%$ of the existing quarries in the Campania region. Of these, 23 are authorized, 23 closed, 180 abandoned. In addition, there are 27 illegal quarries. The open-air typology, on the other hand, present in the majority in the province of Caserta, reviews a total of 422 quarries, approximately $27.5 \%$ of all those in the Campania region and of which, 46 authorized, 59 closed, 317 abandoned. The abandoned quarries in the province of Caserta represent $29.8 \%$ of the regional total [I]. Finally, the 422 are joined by another 36 illegal quarries.

Over time, the intense mining activity conducted in this large territory has changed the image and perceptive-identity character of its places. However, in addition to the mere numerical data, there are no graphic-perceptive studies of the quarries that describe their meanings and return their identity and sense of belonging to the context. For these reasons, this contribution offer to the discipline of representation a theme that increasingly belongs to our territorial realities, with the proposal to return the large schedule of the quarries of the Campania reality no longer as elements of disconnection of the territory but as places from the "possibility of being" (Bachelard 1999, p. 239).

Within this context, the discipline of drawing is an indispensable medium for the study and documentation of quarries, and it is the first operation of objective knowledge and, at the same time, of critical reading.

In this sense, the research, aimed at the acquisition, analysis, systematization and communication of the landscape-territorial configuration of the quarry system (here with first examples in Naples and Caserta), aims to implement the territorial mapping of the extraction sites through the most appropriate techniques and integrated methodologies of surveying for their acquisition, to place a particular reflection on the meaning of the quarry both as an element with the inherent meaning of empty space and as a physical and perceptive space in constant evolution [Santarelli 20 I5, p . 5I].

\section{An integrated approach for multiscalar re-presentation of caves and quarries}

Digitization processes simplify dissemination and management of big data about cultural resources, enriches traditional collections and enhances data/user interaction to preserve and enhance cultural heritage [Bianchini et al.2019]. The main advantages are direct access and clarification of information not yet available. This research activity demonstrates how expeditious reworking and multidisciplinary integration of these data allows the acquisition, modeling, systematization and enhancement of complex landscape-territorial heritage of Campanian caves and quarries. The main goal is alternative outputs for multiscale representation of these elements.

To re-present these informations (maps, censuses, etc.) this paper shows integration of 3D Map digital generators, VPL (Visual Programming Language), GIS (Geographic Information System), digital survey and graphics aimed at management and enhancement of caves and quarries through unpublished and coordinated digital products.

The integration between large scale models and detailed reality-based products allows architectural interpretation of these systems. The main goal is to integrate consolidated approaches to structure new information systems and facilitate digital management of complex morphological-compositional systems. Acquisition, decomposition, management, and 
Fig. I. Acquisition

and explicitation of

digital territorial data for multi-scalar expeditious modeling.VPL definition to combine and manage heterogeneous data of

Caserta territory for

future integration with

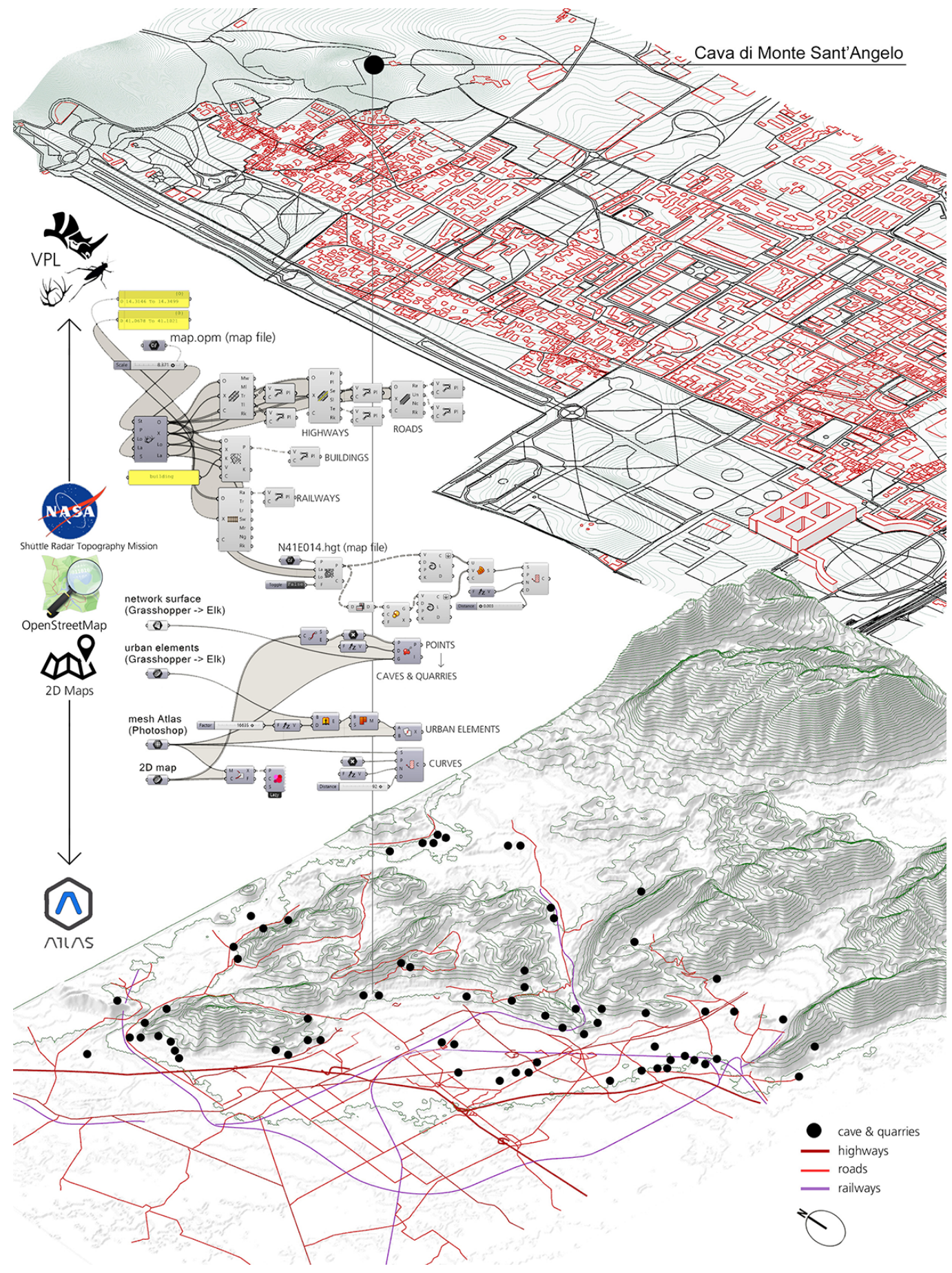


Fig. 2. Modeling, smoothing and contour of NURBS and mesh territorial models. The figure shows the mapping of the most important phegrean caves \& quarries (source: Candone 2008) (source: Cardone 2008) and the Identification of
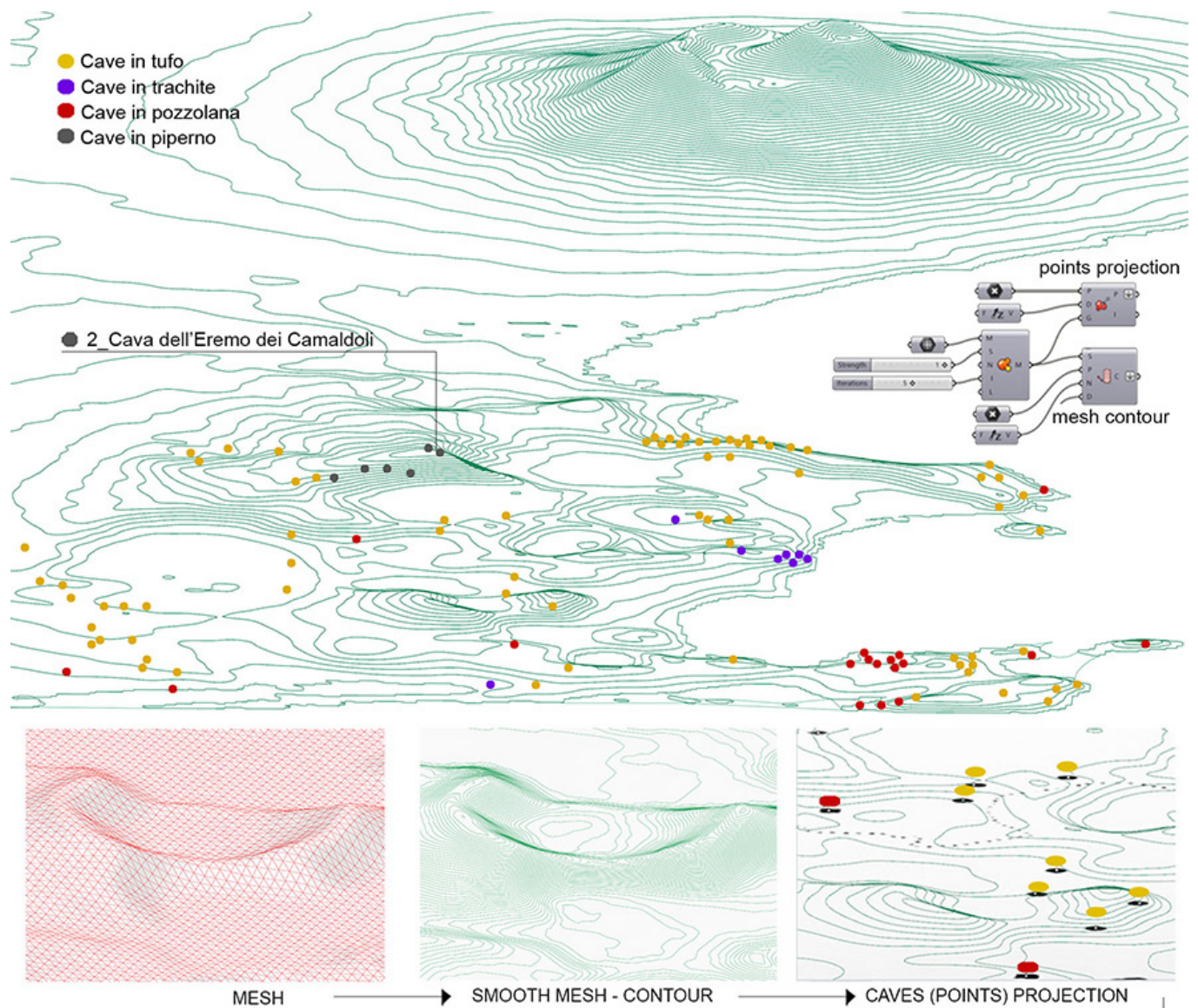

$\Delta 0$

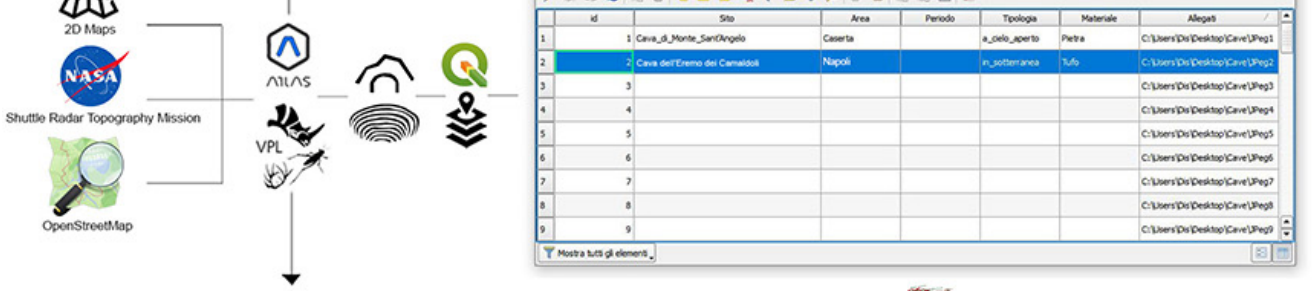

POINTS GRID - SURFACE

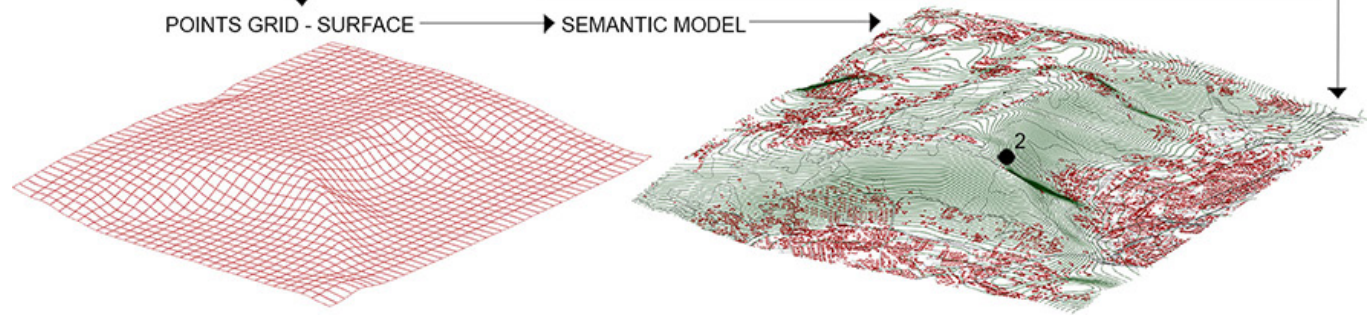


modeling process (Scan to CAD, Scan to HBIM and GIS) of added built territorial systems is aimed at specializing recognizable and manageable objects [Amoruso et al. 20 I9]. A subtraction of a complex element from the landscape-environmental envelope complicates this activity. Current digital tools simplify acquisition, manipulation, and restitution of territorial and urban big data as discrete system (points and curves of networks to return orography, road systems, built systems, etc.). These tools explicate and systematize territorial informations of geolocated map tiles available from digital platforms such as OpenStreetMap and Shuttle Radar Topography Mission (SRTM) (fig. I).

This approach allows transformation and systemisation of heterogeneous data into a synthetic model accessible to many users [Calvano et al. 20I6].

Algorithmic-generative tools (Elk, Mosquito, Grasshopper-Rhino-McNeel add-on) allow to extract a mesh or NURBS DTM (Digital Terrain Model), according to specific server consulted in relation to the area extension, and integrate existing traditional two-dimensional data (graphic maps showing the territorial distribution of quarries cataloged according to a provincial distribution).

Contour and smoothing of digital model characterize graphic outputs.

The identification of main road systems and significant buildings simplifies localization (projection) of caves and quarries case-study on Neapolitan and Caserta territorial areas DTMs (fig. 2).

Future works and experiments about integration between extraction and integration of DEM (Digital Elevation Model) and caves and quarries allow to interpret up and down morphological-compositional relationships between built heritage and these existing natural and artificial elements.

\section{The underground caves. The eremo of Camaldoli}

The city of Naples is located to the center of a volcanic region between the crater building of Vesuvius to the east and the volcanic district of the Campi Flegrei to the west. Almost all the urban agglomeration rises on land born from the volcanic activity of the Phlegraean Fields while the municipal territory on the one hand embraces a significant part of the Phlegrean region and on the other hand encounters stone products from Vesuvius [2].

Within this complex geological structure there are countless underground cavities born from both natural and anthropic phenomena. In the first case, the cavities arise, for example, from the incessant action of the water which in the course of the centuries from the inland to the sea have dug deep furrows in the tuff banks (also on the surface); in the second case, however, the most common reason lies in the extraction of the construction material that often took place in situ. Consequently, it is easy to find a large presence of underground cavities within the urban fabric, many of which are private in nature, with accesses -wells or staircases- which sometimes appear clogged with waste material or completely blocked. Furthermore, the private nature of the latter produces considerable cataloging difficulties which derive from the distrust of many owners and from the extreme division of properties. Within this underground cavities' panorama, usually used for various purposes, often taking
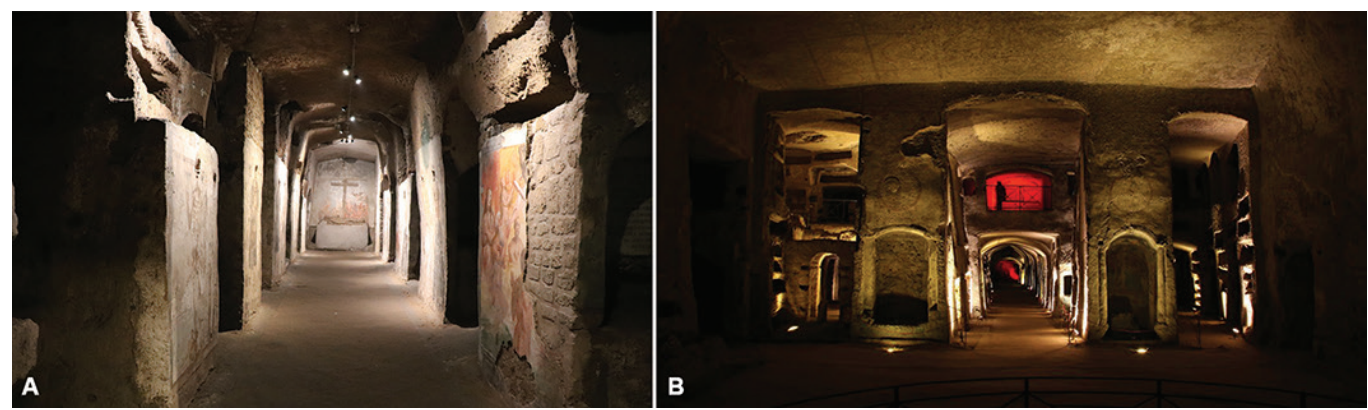


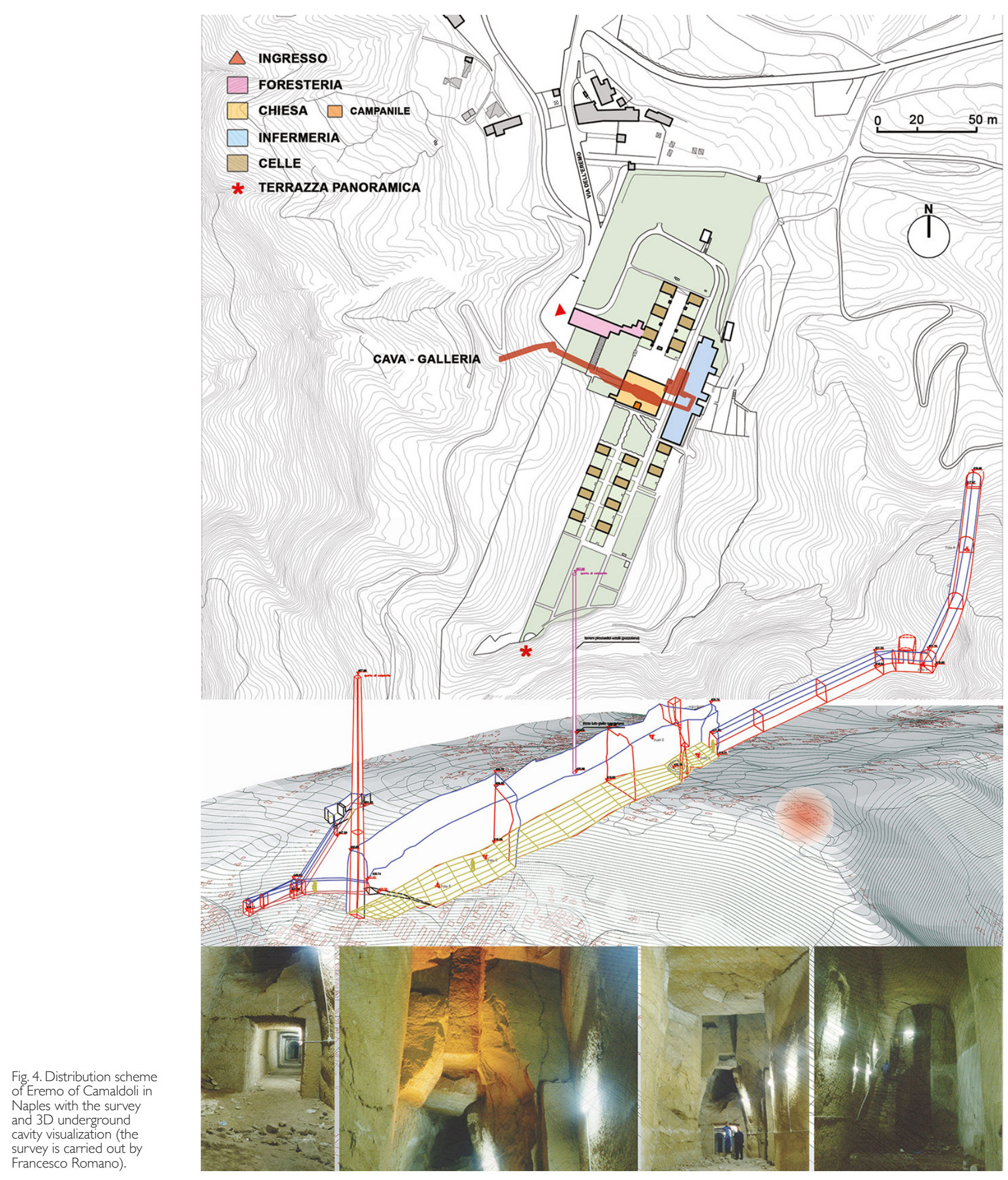


Fig. 5. Planimetry with indication of built areas and quarry areas in the territory of the municipality of Caserta.

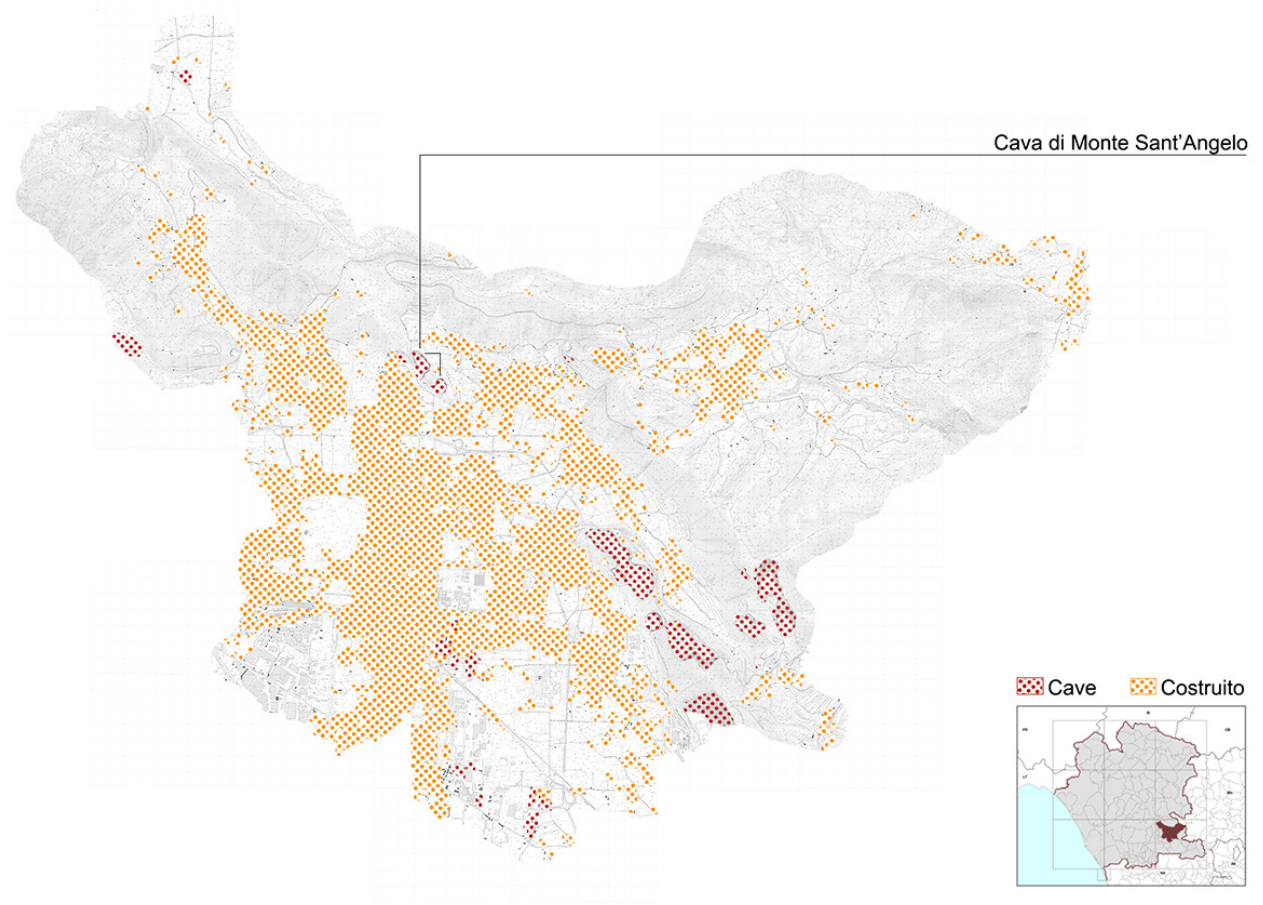

advantage of their specific peculiarities, there are cemeteries, catacombs, galleries, wells, antiaircraft shelters. The caves' current spatial configuration derives from both the underground quarrying method and the excavation techniques adopted and the geo-mechanical characteristics of the extracted material. The most common are the tunnel with side tunnels and pillar chambers [Santarelli 20I5, p. 20]. The first example can be traced back to the catacombs of San Gaudioso, located below the current basilica of Santa Maria della Sanità (fig. 3a); the second, to the catacombs of San Gennaro which are located below the Basilica of Incoronata Madre del Buon Consiglio (fig. 3b).

This contribution offers as a first step the study of the underground cavity located below the eremo of Camaldoli, a monumental religious complex located on the homonymous hill which, with its almost five hundred meters above the level of the sea, it represents the highest elevation in the city [Bossi, Ceratti 1963]. The survey phase of the gallery aims to represent a first way of getting to know the ex-extractive quarries in Naples in the underground, intended as the empty project, and tries to invoke an opening to the collective imagination of quarries places as new elements which may connect the city.
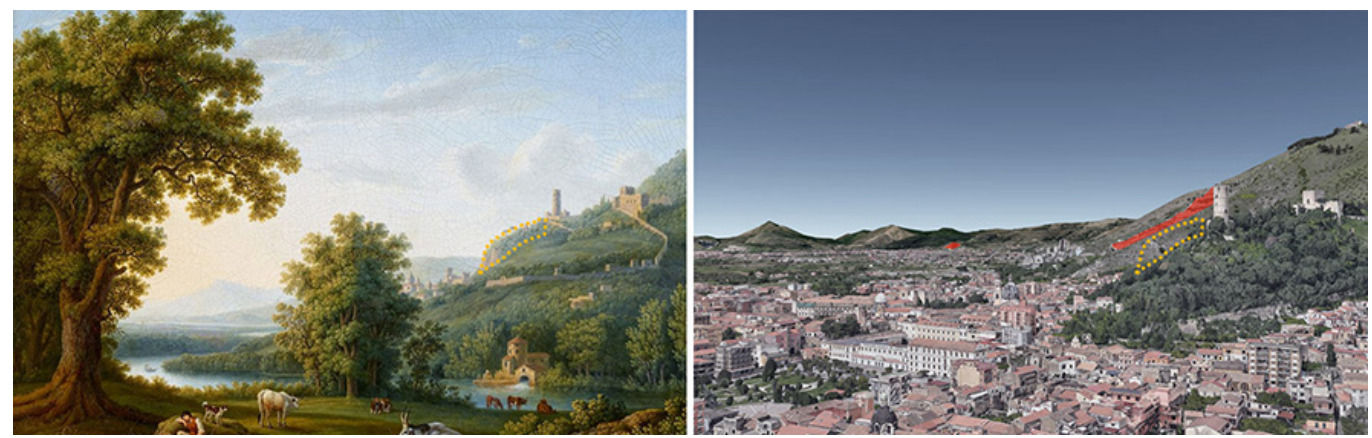

Fig. 6. The landscape system of the Maddalon hills between past and present (in red, the quarries present today, visible from this perspective.

portion of the mountain now absent). 
From a first analysis, the cavity in question is placed in axis with the central nave of the church. The spatial configuration of the cavity can be traced back to a gallery accessible through stairs located in the open space belonging to the Infirmary. The gallery is made up of two oblong spaces with different altimetric sections: the first with a height of about ten meters; the second, smaller, about three meters high. The latter corridor starts and flows onto a secondary road that runs alongside the Hermitage to the west (fig. 4).
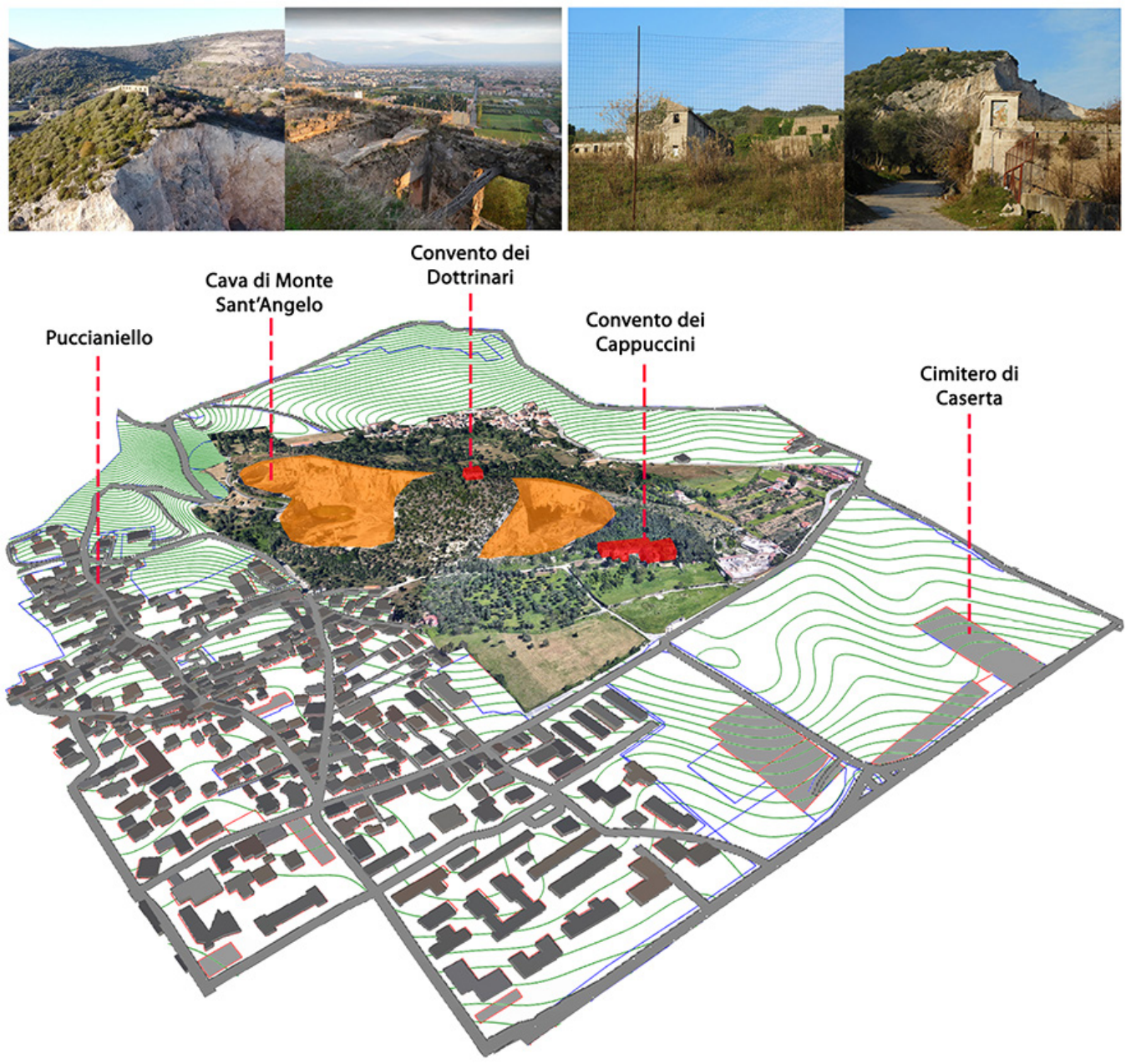

\section{Open-cast quarries. The south slope of the Tifatini mountains}

So-called open-cast quarries represent the main source of raw materials for the Campania territory. This is especially true for the province of Caserta where in the last few decades mining primarily involving calcareous materials has produced quite a few brownfield and abandoned sites along the south slopes of the Tifatini mountains [Buondonno 200 I] (fig. 5 ) at the northern edge of the Campania plain next to the main infrastructure axes. The distinctive terraced areas and empty spaces of the urban context from Capua to Maddaloni (fig. 6) have compromised the perceptive quality of the landscape; in particular, the hillside area in the city of Caserta is characterised by substantial breaches disconnecting the land- 
scape that once acted as the scenic backdrop to the park of the Royal Palace, the spot where visitors chose to take pictures of the Caserta plain (e.g., in the paintings by Jacob Philipp Hackert in the first half of the eighteenth century). The height and direction of the slopes (up to $75 \mathrm{~m}$ ) of monte Sant'Angelo create an important physical and perceptive breach; to the northeast the calcareous rock face rising behind the abandoned convent of the Capuchins in Puccianiello (second half of the sixteenth century) has been created by the recent industrial sprawl that stops very close to the ruins of another convent belonging to the Christian Doctrine Fathers located at the top of the hill (to the northwest), built in the first half of the seventeenth century and now in ruins (fig. 7). The artificial basin can be considered a third landscape (Clément, 2005), the landscape of a border that is not only geographical -transition between city and non-city- but also temporal; a leftover or standby space that can be re-revealed using travellers' images and iconographies. When integrated in a digital model the latter highlight the simplifications, schematisations and perceptive changes that have occurred over the years. The importance of the history and identity of places inspired an analysis that merged the results of an aerial photogrammetric survey using the spatial georeferencing of digital map tiles with traditional iconographic and cartographic sources to describe the site's morphological complexity and propose interpretations (including historical interpretations) of the way in which the areas have been exploited and how this has affected the formation of the built landscape. The survey campaign was performed using a full HD camera with a f/2.8 lens mounted on a DJI Spark drone; the automatic mode flights followed the waypoint flight plan capturing nadiral images on an inclined plane due to the geometric conformation of the site. The SPM algorithms and multi-stereo matching (Velho et al. 2009; Török et al. 2020) enabled the reconstruction of a high-resolution points cloud from which to obtain a DTM, an altimetric model with a regular grid, a .tiff spot height map implemented in a GIS environment. A comparison and integration with the territorial morphology taken from satellite maps (fig. 8) underscores how important it is to obtain more accurate survey data given the complexity of the structures present. This data can be used to: control the evolution of the disruptive conditions; draft cultivation projects; develop critical thematisms of pre- and post-design simulations to support environmental restora-
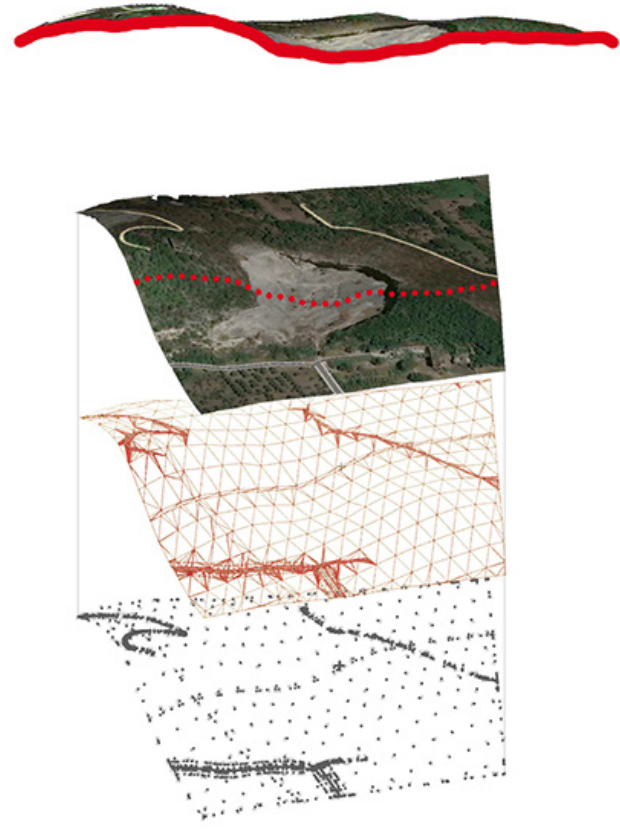
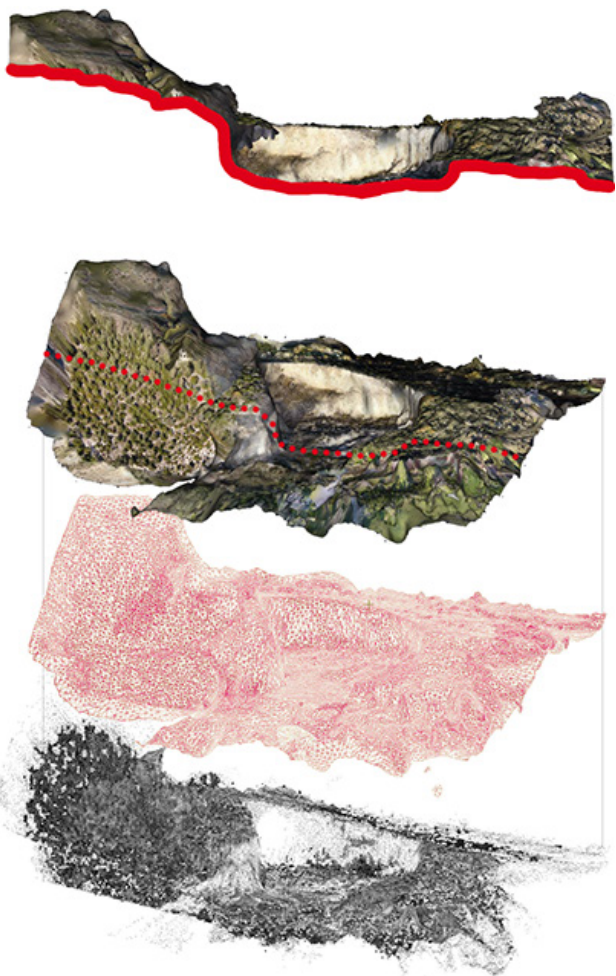
tion; rethink a renewed use of the quarry sites by exploiting modern integrated visualisation systems that help us understand and further explore our lost heritage. It will recreate the view visitors saw in the eighteenth century in a beautiful, georeferenced virtual setting, illustrating not only the cartographic and geometric-configurative element, but also the original physical and perceptive relations created between space and the context [Liuzzo, Giuliano 2016] (fig. 9).

\section{Conclusions and future developments}

The different approaches adopted for the data acquisition have made possible a rapidly approach for digital modeling and management of the territorial system of study, from the big to detail scale. Through the digital construction of a multilevel database, this study hopes the creation of a digital platform development to enhance and disseminate the features of a complex, hybrid urban and landscape reality, characterized by the presence of fragmented spaces, sometimes degraded, as well as considering the possibility of genius loci recovery through the aid of drawing intended as an analysis tool between thought and design [3].
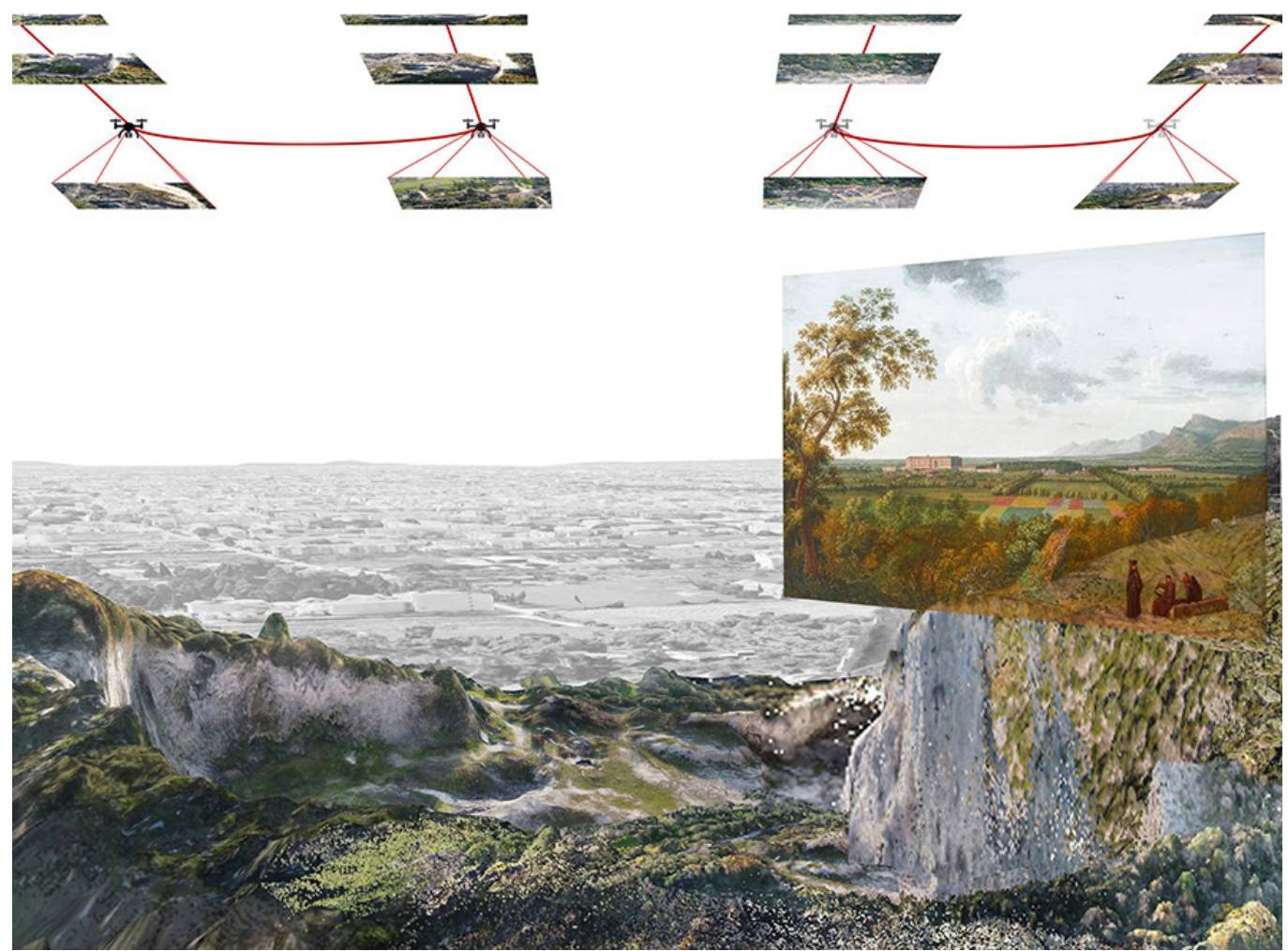

Notes

[I] Linee Guida del Piano Regionale Attività Estrattive - Supplementary document and update to the Final Report referred to the "Delibera di Giunta Regionale" № 7253, december 27, 200I - June 2006.

[2] II sottosuolo di Napoli. Relazione della commissione di Studio. Edit by Comune di Napoli, 1967.

[3] This contribution is written in all its parts and belongs to all the co-authors. 


\section{References}

Amoruso Giuseppe, Mironenko Polina (2019). Heritage BIM descriptive models for the representation of resilient city. The case of Amatrice's reconstruction. In Belardi Paolo (a cura di). Riflessioni/Reflections. L'arte del disegnolil disegno dell'arte. The art of drawing/the drawing of art. Atte del $41^{\circ}$ Convegno Internazionale dei Docenti delle Discipline della Rappresentazione. Perugia 19-2I settembre 20 19. Roma: Gangemi Editore, pp. I051-1056.

Bachelard Gaston (1999). La poetica dello spazio. Bari: Dedalo.

Bianchini Carlo, Casale Andrea, Empler Tommaso et al. (2019). Ecosistemi digitali - Digital Ecosystem. In Paesaggio urbano, |.2019, pp. 42-5।.

Bossi Paolo, Ceratti Alessandro (1993). Eremi camaldolesi in Italia. Luoghi architettura spiritualità. Milano:Vita e Pensiero.

Buondonno Andrea (200 I). Le aree di cava della città di Caserta: dal dissesto geopedologico alla riqualificazione ambientale. In Rigillo Marina et al. (a cura di). La Città continua. Il sistema urbano da Capua a Maddaloni. Caserta: L'Aperia editore, pp. 77-84.

Calvano Michele, Guadagnoli Francesca (2016). Ricostruzione 3D della città di Amatrice. Una operazione di 'instant modeling'. In DisegnareCon. n. 17, 2019 , vol. 9, pp. 7.1-7.9.

Cardone Vito (2008). Modelli grafici dell'architettura e del territorio. Salerno: Cues.

Clément Gille (2005). Manifesto del Terzo Paesaggio. Macerata: Quodlibet

Conti Simonetta, Valerio Vladimiro (2012). La Terra di Lavoro nella Storia. Dalla Cartografia al Vedutismo. Roma: Associazione Roberto Almagià. pp. 102-103.

Liuzzo Mariangela, Giuliano Sebastiano (2016). Dal rilievo alla divulgazione: metodologie integrate per la fruizione virtuale de territorio. In Capano Francesca, Pascariello Maria Ines, Visone Massimo (a cura di). Delli Aspetti de Paesi. Vecchi e nuovi Media per I'Immagine del Paesaggio. Napoli: FedOA - Federico II University Press, pp. 327- 336

Santarelli Isabella (20I5). Riscritture per il sottoruolo ex-estrattivo. Strategie di recupero tra memoria, tutela ambientale e nuovi usi per la città contemporanea. Tesi di Dottorato di Ricerca XXVIII ciclo. Sapienza Università di Roma. DiAP, p. 20.

Török Ákos, Bögöly Gyula, Somogyi Árpád, Lovas Tamás (2020). Application of UAV in Topographic Modelling and Structural Geological Mapping of Quarries and Their Surroundings - Delineation of Fault-Bordered Raw Material Reserves. In Sensors 2020, 20, n. 489

Trasi Nicoletta (200 I). Paesaggi rifiutati Paesaggi riciclati. Prospettive e approcci contemporanei. Roma: Editrice Librerie Dedalo. Velho Luiz, Frery Alejandro C., Gomes Jonas (2009). Image Processing for Computer Graphics and Vision. Cham: Springer.

\section{Authors}

Giuseppe Antuono, Università degli Studi di Napoli “Federico II”, giuseppe.antuono@unina.it

Valeria Cera, Università degli Studi di Napoli "Federico II", valeria.cera@unina.it

Vincenzo Cirillo, Università degli Studi della Campania “Luigi Vanvitelli”, vincenzo.cirillo@unicampania.it

Emanuela Lanzara, Università degli Studi di Napoli “Federico II", emanuela.lanzara@unina.it

To cite this chapter. Antuono Giuseppe, Cera Valeria, Cirillo Vincenzo, Lanzara Emanuela (2020). ex-caV/ARe. Ibridazioni digitali per la ri-presentazione delle cave campane/ex-caV/ARe. Digital hybrids to re-present campanian caves\&quarries. In Arena A., Arena M., Brandolino R.G., Colistra D. Ginex G., Mediati D., Nucifora S., Raffa P. (a cura di). Connettere. Un disegno per annodare e tessere. Atti del $42^{\circ}$ Convegno Internazionale dei Docenti delle Discipline della Rappresentazione/Connecting. Drawing for weaving relationships. Proceedings of the 42th International Conference of Representation Disciplines Teachers. Milano: FrancoAngeli, pp. 1 556-1 577. 